\title{
Late Holocene landscape change history related to the Alpine Fault determined from drowned forests in Lake Poerua, Westland, New Zealand
}

\author{
R. M. Langridge ${ }^{1}$, R. Basili ${ }^{2}$, L. Basher ${ }^{3}$, and A. P. Wells ${ }^{4}$ \\ ${ }^{1}$ GNS Science, P.O. Box 30-368, Lower Hutt, New Zealand \\ ${ }^{2}$ Istituto Nazionale di Geofisica e Vulcanologia, Via di Vigna Murata 605, 00143 Rome, Italy \\ ${ }^{3}$ Landcare Research NZ Ltd., Private Bag 6, Nelson 7042, New Zealand \\ ${ }^{4} \mathrm{c} /$-2 McLennan Rd, R D Hawea, Luggate, New Zelaand \\ Correspondence to: R. M. Langridge (r.langridge@gns.cri.nz)
}

Received: 25 July 2011 - Revised: 5 March 2012 - Accepted: 14 March 2012 - Published: 26 June 2012

\begin{abstract}
Lake Poerua is a small, shallow lake that abuts the scarp of the Alpine Fault on the West Coast of New Zealand's South Island. Radiocarbon dates from drowned podocarp trees on the lake floor, a sediment core from a rangefront alluvial fan, and living tree ring ages have been used to deduce the late Holocene history of the lake. Remnant drowned stumps of kahikatea (Dacrycarpus dacrydioides) at $1.7-1.9 \mathrm{~m}$ water depth yield a preferred time-ofdeath age at $1766-1807 \mathrm{AD}$, while a dryland podocarp and kahikatea stumps at $2.4-2.6 \mathrm{~m}$ yield preferred time-of-death ages of ca. 1459-1626 AD. These age ranges are matched to, but offset from, the timings of Alpine Fault rupture events at ca. $1717 \mathrm{AD}$, and either ca. 1615 or $1430 \mathrm{AD}$. Alluvial fan detritus dated from a core into the toe of a rangefront alluvial fan, at an equivalent depth to the maximum depth of the modern lake $(6.7 \mathrm{~m})$, yields a calibrated age of $\mathrm{AD}$ 1223-1413. This age is similar to the timing of an earlier Alpine Fault rupture event at ca. $1230 \mathrm{AD} \pm 50$ yr. Kahikatea trees growing on rangefront fans give ages of up to $270 \mathrm{yr}$, which is consistent with alluvial fan aggradation following the $1717 \mathrm{AD}$ earthquake. The elevation levels of the lake and fan imply a causal and chronological link between lake-level rise and Alpine Fault rupture. The results of this study suggest that the growth of large, coalescing alluvial fans (Dry and Evans Creek fans) originating from landslides within the rangefront of the Alpine Fault and the rise in the level of Lake Poerua may occur within a decade or so of large Alpine Fault earthquakes that rupture adjacent to this area. These rises have in turn drowned lowland forests that fringed the
\end{abstract}

lake. Radiocarbon chronologies built using OxCal show that a series of massive landscape changes beginning with fault rupture, followed by landsliding, fan sedimentation and lake expansion. However, drowned Kahikatea trees may be poor candidates for intimately dating these events, as they may be able to tolerate water for several decades after metre-scale lake level rises have occurred.

\section{Introduction}

Onland studies of paleoseismicity have traditionally been focused on subaerial environments where records of direct, on-fault deformation can be obtained (see McCalpin, 2009). However, lakes and their sediments hold a considerable record of the geologic history of onland subaqueous environments (Nichols, 2009). Cycles and fluctuations of sedimentation within Pliocene and Quaternary lake basins are commonly used to assess the record of climate change onland (Smith, 2000; Reid and Frostick, 1993; Cavinato et al., 2000; Negrini, 2002). Lake sediments also act as superb paleoseismic indicators as the sediments are sensitive to levels of past earthquake shaking (Sims, 1975; Hibsch et al., 1996). Therefore, the paleoseismology of lakes and lacustrine deposits can be considered an important branch of subaqueous paleoseismology (Goldfinger, 2009). In parts of the world with long historical earthquake records, e.g. the Mediterranean region (Kagan et al., 2011; Marco et al., 1996, 2003), the paleoseismic record from lakes complements historical earthquake 


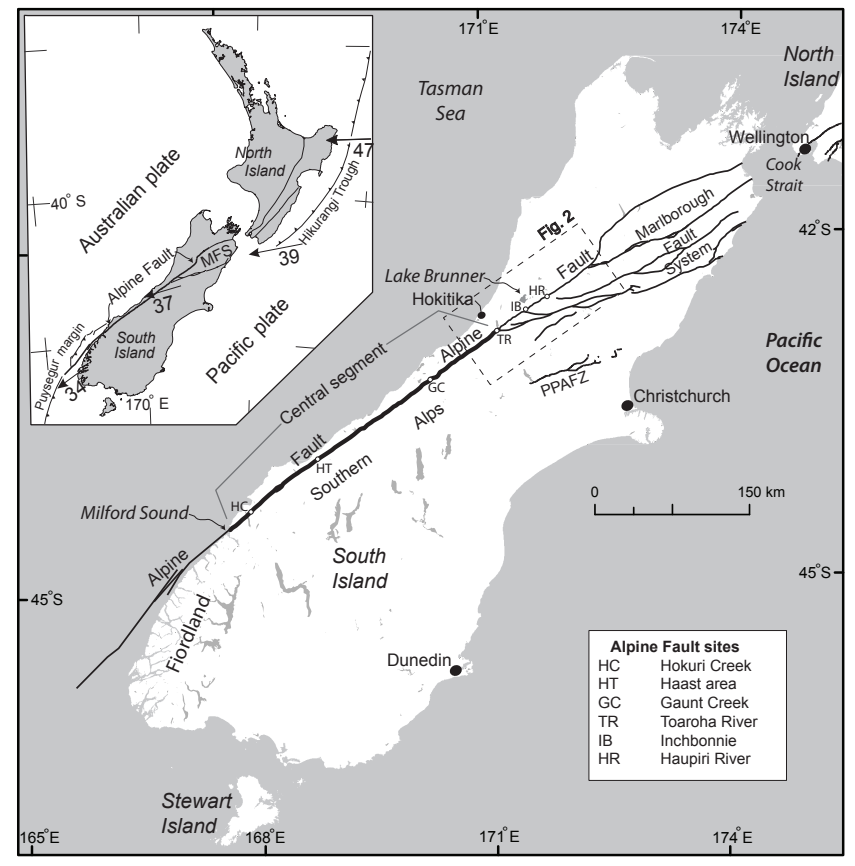

Fig. 1. Tectonic setting of South Island highlighting the Alpine Fault, Marlborough Fault System (MFS) and Porters PassAmberley Fault Zone (PPAFZ). The Central segment of the Alpine Fault is marked in bold. Alpine Fault paleoseismic sites are shown in the legend. Lake Poerua is located between Lake Brunner and Inchbonnie. Inset: Relative motion between the Pacific and Australian plates is shown in $\mathrm{mm} \mathrm{yr}^{-1}$ from De Mets et al. (1994).

records, while in more recently colonised areas of the world, such as the western United Sates and New Zealand, attaining paleoseismic records from lacustrine settings has the potential to yield important information on the timing, intensities and magnitudes of past events (Howarth et al., 2011; Philibosian et al., 2011; Langridge et al., 2001).

In contrast to presenting a lacustrine paleoseismic sedimentary record, in this novel study we have investigated a record of Holocene lacustrine geomorphic change. This study deals with the drowning of forests in a small and young lake in the West Coast region of New Zealand (Figs. 1 and 2). Tree stumps were located on the floor of, and around the fringes of, Lake Poerua, which is bounded on one side by the main fault scarp of the Alpine Fault (Fig. 3). Tree stumps from within the lake were probably drowned following rises in the relative level of Lake Poerua. We dated these stumps using radiocarbon dating, and in two cases we use annular tree rings and the age sequencing capabilities of the OxCal calibration program (e.g. Bronk Ramsey, 2007; Biasi and Weldon, 1994) that allow precise "timeof-death" and "seedling-ages" of two trees to be estimated. Drowned or down-dropped trees have been successfully used as chronometers in other paleoseismic studies, e.g. along the Cascadia subduction margin of western North America (Clague, 1997; Nelson et al., 1995; Jacoby et al., 1997). In addition, we use a sediment core from an alluvial fan fringing the lake to assess the age and growth rate of alluvial fans around the valley, and have cored standing native trees to assess the surface age of these same fans. These three techniques allow us to assess the interplay between late Holocene tectonic (relative uplift/subsidence), geomorphic and sedimentary processes between the rangefront, alluvial fans and the lake itself.

A goal of this preliminary study was to consider whether the time-of-death ages of these trees are consistent with other on- and off-fault paleoseismic ages for the Alpine Fault (e.g. Wells et al., 1999, 2001; Sutherland et al., 2007), and if so, what mechanism linked the rupture of the fault with a rise in relative lake level capable of drowning living forests. Precise dating also allowed for an assessment of the rapidity of landscape change and the time to re-stabilise the landscape following large to great Alpine Fault earthquakes.

\section{Background geology}

\subsection{The Alpine Fault}

The Alpine Fault is an active dextral-reverse slip fault that forms the major boundary between the Australian and $\mathrm{Pa}$ cific plates across the South Island of New Zealand (Wellman, 1955; Cox and Sutherland, 2007; Berryman et al., 1992) (Fig. 1). The central segment of the fault, between Fiordland in the southwest to near Hokitika in the northeast, has estimated late Quaternary dextral slip rates of ca. 23$27 \mathrm{~mm} \mathrm{yr}^{-1}$ and vertical slip rates of up to ca. $10 \mathrm{~mm} \mathrm{yr}^{-1}$ along much of its length (Fig. 2) (Norris and Cooper, 2001; Sutherland et al., 2006). Northeast of Hokitika, the slip rate of the Alpine Fault decreases as plate boundary strain is distributed across a zone of strike-slip faulting called the Marlborough Fault System (Van Dissen and Yeats, 1991; Langridge and Berryman, 2005; Langridge et al., 2010).

The Alpine Fault is capable of generating large to great earthquakes $\left(M_{\mathrm{W}}=7\right.$ to $\left.>8\right)$ that rupture the fault over hundreds of kilometres every few hundred years (Yetton and Wells, 2010; Sutherland et al., 2007; Berryman et al., 2012). Despite the short recurrence interval (300-400 yr), the Alpine Fault is unique amongst major strike-slip plate boundary faults as it has not had a historical surface-rupturing earthquake event (Yetton, 2000; Berryman et al., 1992, 2012). This is due in large part to the short historical record in New Zealand, where European colonisation did not begin in earnest until $1840 \mathrm{AD}$. Because of this, the earthquake record for the Alpine Fault has been derived entirely from paleoearthquake studies. Although there have been some on-fault trenching studies (e.g. Yetton, 1998, 2000; Berryman et al., 2012), paleoseismic studies have been dominated by off-fault data that rely on dating landscape surfaces using dendrochronology (e.g. Yetton and Wells, 2010; Wells et al., 1999, 2001). Dendrochronolgic studies have been 


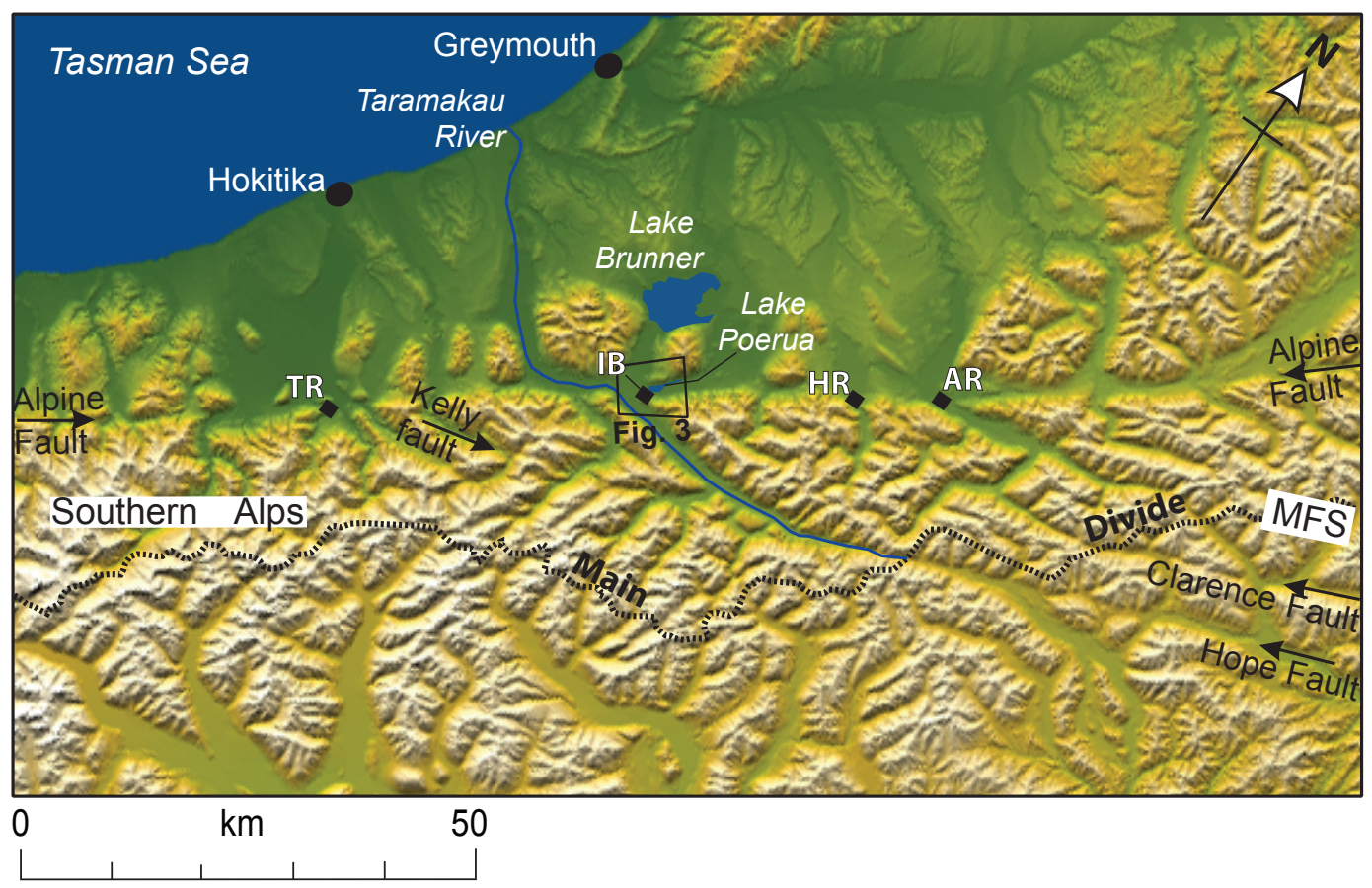

Fig. 2. Colour digital elevation map of central Westland, rotated to emphasise the Alpine Fault. Inchbonnie (IB) and Lake Poerua are located within the small box marked as Fig. 3. In this area, plate motion is transferred to faults of the Marlborough Fault System (MFS). The Taramakau River (blue line) is shown from the Main Divide of the Southern Alps (black dotted line) to the coast. Alpine Fault paleoseismic sites, including Ahaura River (AR) are shown by diamonds.

undertaken at geomorphic settings that include young landslide deposits and scars (Adams 1980; Yetton 1998), alluvial terraces and fans (Yetton, 2000; Cullen et al., 2003; Wells et al., 2001), and coastal sand dunes (Wells and Goff, 2007). Estimated ages for the four most recent major ruptures along the length of the Alpine Fault are ca. $1717 \mathrm{AD}, 1615 \mathrm{AD} \pm 5 \mathrm{yr}$, $1430 \mathrm{AD} \pm 15 \mathrm{yr}$ and $1230 \mathrm{AD} \pm 50 \mathrm{yr}$ (Yetton and Wells, 2010; Rhoades and Van Dissen, 2003). The precision of these ages reflects the precision of dendrochronology and recognition of growth suppression and release seen in tree rings that indicate stresses on forest populations due to significant natural events, such as large earthquakes (Wells et al., 1999).

\subsection{Lake Poerua and setting}

Lake Poerua is a small lake $\left(2.1 \mathrm{~km}^{2}\right)$ located adjacent to the Alpine Fault near the settlement of Inchbonnie and the Taramakau River (Figs. 2 and 3). The lake is shallow with a maximum depth of $6.7 \mathrm{~m}$ (Irwin, 1982) and has a surface elevation of $125 \mathrm{~m}$ a.s.l. The lake was first described by Europeans from the journeys of Sir Julius von Haast, who explored parts of the West Coast region during the 1860's (von Haast, 1948). Holocene Lake Poerua fills part of a former glacial trough, called the Poerua sub-lobe of the former Taramakau glacier by Langridge et al. (2010). The Poerua sublobe was one of three distributary outflow lobes that spread out from the Taramakau glacier on the northwest side of the
Alpine Fault during Last Glacial Maximum (LGM; Suggate and Waight, 1999; Suggate, 1965; Alloway et al., 2007; Barrell et al., 2011) (Fig. 2). However, unlike the nearby, larger Lake Brunner, which has bathymetry of $>100 \mathrm{~m}$ water depth and is bounded by end moraines from the LGM, Lake Poerua is not dammed by moraines and is therefore not directly of glacial origin. Instead, Langridge et al. (2010) argue that Lake Poerua is very young and has formed since the abandonment of the Poerua sub-lobe (Poerua River valley) by the Taramakau River due to avulsion of that river toward the southwest.

Lake Poerua effectively sits astride the Australia-Pacific plate boundary with Australian plate rocks (locally granites) to the west and Pacific plate rocks (metasediments) to the east (Suggate and Waight, 1999; Nathan et al., 2002). The margins of Lake Poerua follow the northeast-trending, uniaxial form of the Poerua sub-lobe of the Taramakau valley, bounded by the Te Kinga granitic massif on its northwestern side; and, on the eastern side of the valley by a scarp of the Alpine Fault which forms a linear shorefront; and by a series of coalescing alluvial fans that emanate from the rangefront of the Alpine Fault and Southern Alps (Figs. 3 and 4). The lake is fed by streams flowing from the valley walls and from groundwater flow through Taramakau River gravels on its south side. The bathymetry of the lake follows the topography of the lake sides, with a generally shallower lake floor 


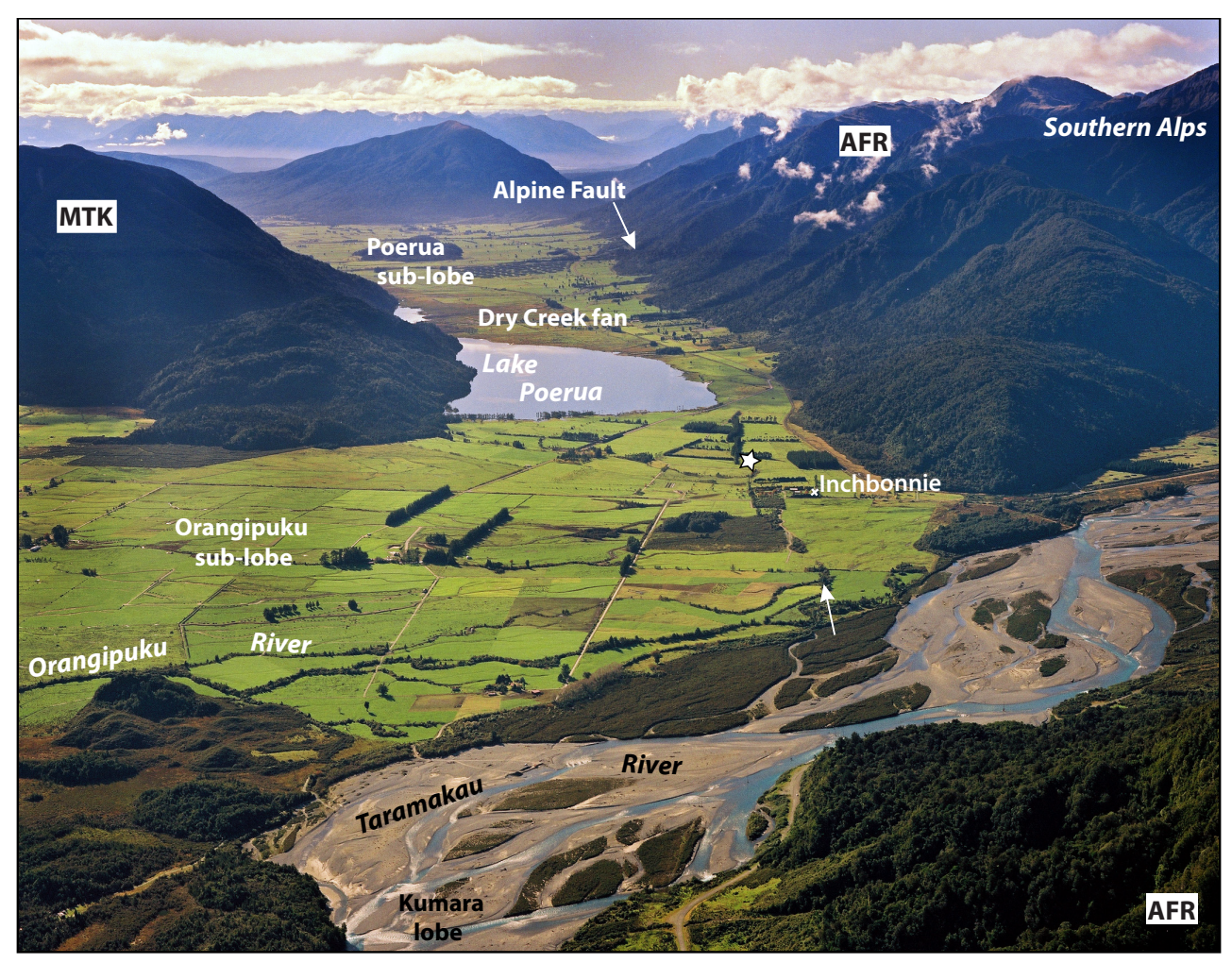

Fig. 3. Oblique aerial photograph of the Inchbonnie area viewed to the northeast toward Lake Poerua and the Alpine Fault (indicated by white arrows). The fault is characterised by a series of stepping fault traces from the river to Lake Poerua, across abandoned terraces of the Taramakau River. Abbreviations are: AFR, Alpine Fault rangefront along the edge of the Southern Alps; MTK, Mt. Te Kinga granitic massif. The Inchbonnie paleoseismic trench site is marked by a star (Photo: Lloyd Homer, GNS Science).

gradient at the long axis ends of the lake, and a steep sided lake shore against the edges of Mount Te Kinga. Lake Poerua drains to the north via Poerua Stream to Lake Brunner.

In its modern setting, native kahikatea (Dacrycarpus dacrydioides) stands occur on the southern lake shore, while remnant native forests of less water-tolerant podocarps (Family Podocarpacae) cover the steeper sides of the valley, including on stabilised alluvial fan surfaces that emanate from the rangefront of the Alpine Fault. Reconnaissance in 2005 revealed the presence of many tree stumps on the floor of the lake, indicating that the relative lake level was considerably lower at some recent time. We also received anecdotal evidence of a stone circle or fire ring having been sited on the lake floor near its southwestern corner. Additionally, a single, large standing tree stump on the south shore of the lake was extensively dated to estimate the age of the alluvial surface bounding Lake Poerua. This tree - probably Matai ( Prumnopitys taxifolia) - colonised a well-drained, abandoned alluvial surface of the former Taramakau River, termed the Inchbonnie-3 (I-3) surface, between ca. 15301670 cal yr BP (Langridge et al., 2010).

The hypothesis of this study was that Lake Poerua has progressively grown in area and depth during the last millennia or more due to changes in the sill level of the lake, which we infer is intimately linked to large seismic events on the Alpine Fault. Ultimately, the relative level of water in such a lake may be complex and may be derived from an interplay between tectonics (subsidence/uplift), geomorphology (sill level), and sedimentation (sediment supply, climatic effects).

A simplified model of how lake-level change affects lowland forest stands around Lake Poerua is shown in Fig. 5. Changes in the position of the paleo-shorelines is reflected by the extermination of fringing forests through drowning of trees in the rising lake. These trees can be precisely dated using radiocarbon dating to estimate times of punctuated lakelevel change. This method could also provide information on the time taken for local landscapes to respond and re-stabilise following Alpine Fault earthquakes. Caveats to this model include: (i) the observation of small seasonal and punctuated changes in lake-level in recent decades due to landslip blockages; and (ii) that some tree species, particularly kahikatea, are moderately water-tolerant trees. Kahikatea is often thought of as a swamp forest tree, but it can live in a range of sites (Dawson and Lucas, 2011; Wardle, 1974). Kahikatea are more abundant on wet soils because they can tolerate waterlogging better than many other native tree species, particularly broadleaved trees which out-compete 


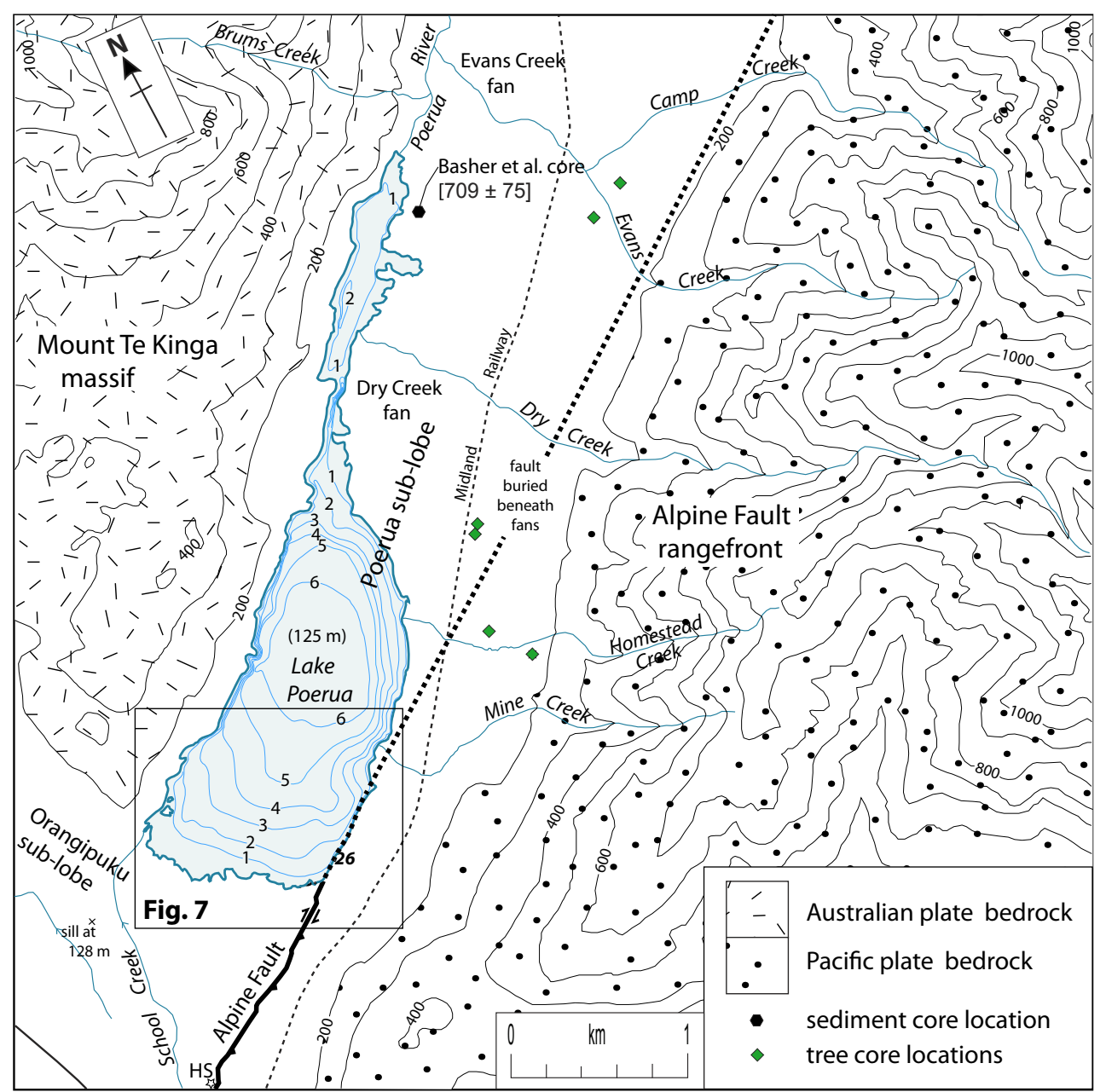

Fig. 4. Map of the Inchbonnie-Poerua area, highlighting the bathymetry of Lake Poerua (in m). Contour interval for the valley is $100 \mathrm{~m}$. Subaerial traces of the Alpine Fault and the Inchbonnie trench site (HS) are indicated at bottom left. All located tree stumps occur within box marked Fig. 7. A core from near the northern tip of the lake has a single radiocarbon date. Trees cored for dendrochronologic ages are indicated by diamonds.

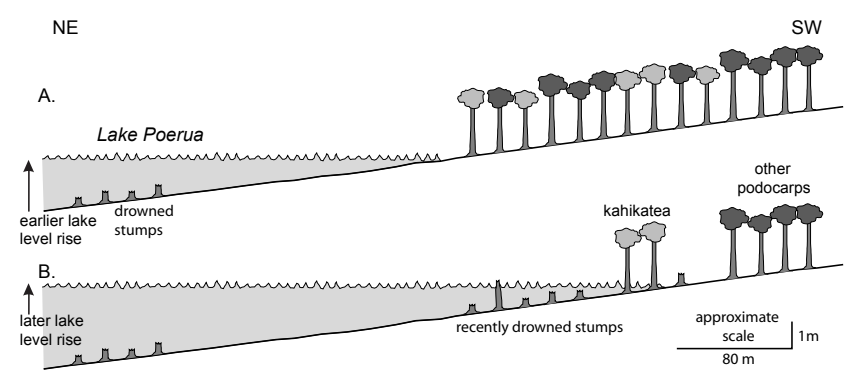

Fig. 5. Model of the relationship between fringing lowland forest and lake level change at the southern end of Lake Poerua. (A) Drowned trees indicate an earlier lake level rise. (B) a second lake level rise kills off trees surrounding the lake shore. Some kahikatea trees near the lake shore may survive in shallow water near the new lake shore. kahikatea in drier conditions. In wet conditions, kahikatea are observed to form strong basal buttresses that provide both stability and increased opportunity to draw oxygen (Dawson and Lucas, 2011). Our observations show that kahikatea can in fact survive in water up to $0.4 \mathrm{~m}$ depth, as observed at the southwestern corner of Lake Poerua today.

\section{Tree sampling and dating}

Wood for radiocarbon dating was collected from seven stumps from the floor and shore of the lake (Fig. 6; Table 1). Underwater samples were collected using a snorkel and handsaw, allowing only small samples from the outside part of the stumps to be obtained for dating (Fig. 7). The tree species was difficult to determine for those that came from small samples from deep water. Stumps WP26 and WP119 were confirmed as being kahikatea. Results of dating 

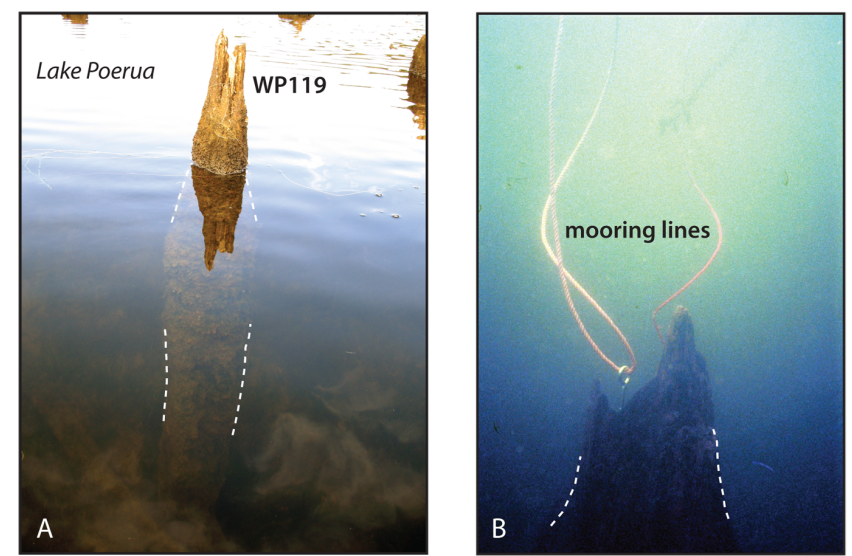

Fig. 6. Photographs of drowned trees within Lake Poerua. (A) Barely emergent tree stump WP119 in ca. $1.8 \mathrm{~m}$ of water (B) stump WP4 on the floor of the lake in ca. $2.5 \mathrm{~m}$ of water. Mooring lines were attached to the stump for continued relocation and sampling. Dashed white lines mark the sides of the stumps.

presented in the text represent radiocarbon dates and 2-sigma calendar calibrated ages.

\subsection{Exterior stump dates}

Table 1 shows radiocarbon dating results from the exteriors of seven tree stumps. Stumps WP26 and WP3, at the southeast corner of the lake, were collected along a $107 \mathrm{~m}$ long transect along the lake floor where the water depth and the lake floor gradient were measured to locate the trace of the Alpine Fault (Figs. $6 \mathrm{~b}$ and 8 ). The topographic profile confirmed that the lake floor is gently sloping and that the scarp of the Alpine Fault forms the current lake edge there (Irwin, 1982; Langridge and McSaveney 2008). A tree ring sampled from near the outside of stump WP26 (18 rings in), on the southeast shore of the lake, yielded an age of $128 \pm 35$ radiocarbon yr BP (calibrated to $1697-1950 \mathrm{AD}$ ). A grab sample from the outside of stump WP3, $107 \mathrm{~m}$ from the lake shore and at a water depth of $1.9 \mathrm{~m}$, yielded an age of $249 \pm 30$ yr BP (1638-1803 AD). Farther from the shore, and at depths of 2.4, 2.5 and $2.6 \mathrm{~m}$, wood from near the outside of stumps WP7, WP4, and WP5 yielded ages of $357 \pm 15 \mathrm{yr}$ BP (1500-1635 AD), $390 \pm 25$ yr BP (1459-1627 AD), and $454 \pm 30$ yr BP (1436-1612 AD), respectively (Fig. 7). At the southwestern edge of the lake, a cluster of stumps that barely emerged above the lake surface and stand in ca. $1.8 \mathrm{~m}$ of water were located (Fig. 6). Sample WP119-7 from near the outside of one of these stumps (i.e. 7 rings in from surviving bark), yielded an age of $190 \pm 20 \mathrm{yr}$ BP (1668-1950 AD).

\subsection{Stumps with multiple dates}

In addition to dates from grab samples on the outsides of stumps, we dated samples from the interiors of stumps WP26

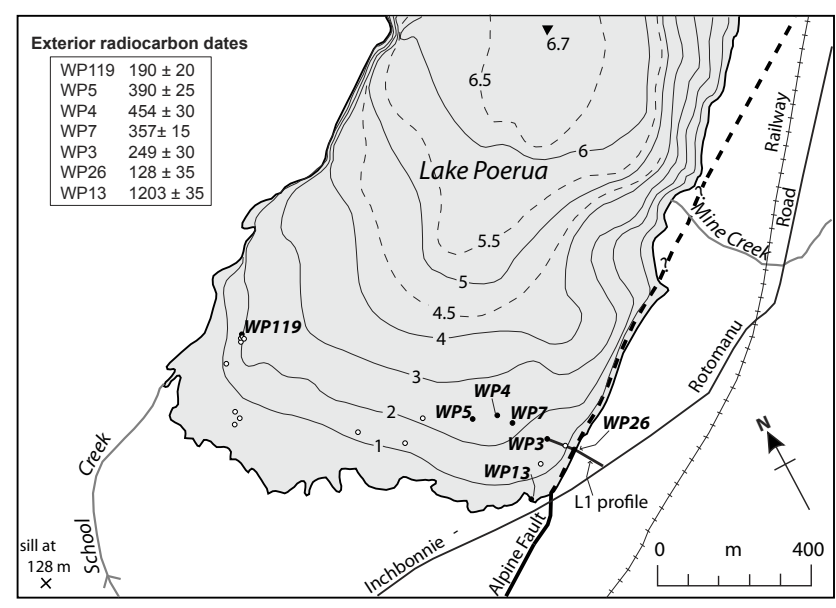

Fig. 7. Bathymetric map of the southern half of Lake Poerua, with contours every $0.5-1 \mathrm{~m}$ (after Irwin, 1982). GPS surveyed tree stumps are shown by filled (radiocarbon dated) and unfilled circles. Exterior radiocarbon dates for these stumps are indicated at top left. Traces of the Alpine Fault are shown on land and dashed along the southeastern shore of the lake and beneath the Mine Creek fan where concealed. Bold line (L1 profile) represents the topographicbathymetric profile shown in Fig. 8.

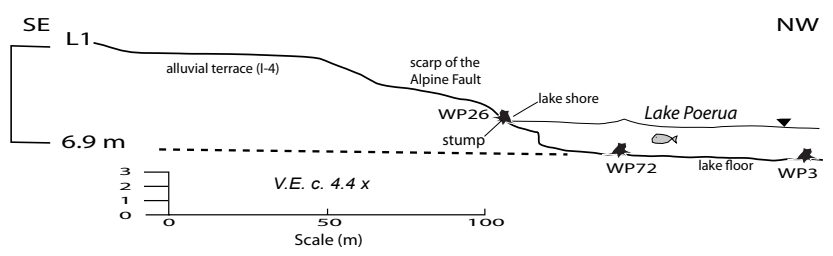

Fig. 8. Combined topographic profile constructed using a RTK-GPS (onland) and rod and tape (in lake). Profile L1 was measured from the road to stump WP3 on the lake floor. The height difference between alluvial surface I-4 and the lake floor (ca. $6.9 \mathrm{~m}$ ) is equivalent to the vertical deformation across the Alpine Fault since the abandonment of the I-4 surface (see Langridge et al., 2010).

and WP119 to better characterise the life history of these trees. The goal with these samples was to combine dendrochronology with radiocarbon dating through the OxCal statistical program (Bronk Ramsey, 2007), to better define the time-of-death age of these trees, i.e. a more precise estimate of when the tree died. Kahikatea stump WP26 had an approximate diameter of $34 \mathrm{~cm}$. An entire slab section was sawn and polished from this stump and 50 rings were counted to reach the centre of the tree, sampled at ground level on the lake shore. Sample WP26-40 was 40 rings from the exterior bark layer of the tree, and yielded an age of $272 \pm 15 \mathrm{yr} \mathrm{BP}$ (1636-1795 AD).

WP119, also a kahikatea, had an approximate diameter of $25 \mathrm{~cm}$. To sample a whole section from this stump at ca. $1.6 \mathrm{~m}$ above root base of the stump in $1.8 \mathrm{~m}$ of water, we constructed a simple beam platform in between WP119 and 
Table 1. Summary of radiocarbon dates from the Lake Poerua area.

\begin{tabular}{|c|c|c|c|c|c|c|}
\hline \multirow{2}{*}{$\begin{array}{l}\text { Location } \\
\text { and } \\
\text { sample ID }\end{array}$} & \multirow{2}{*}{$\begin{array}{c}\text { NZA Lab } \\
\text { no. }\end{array}$} & \multirow{2}{*}{ del 13C } & \multirow{2}{*}{$\begin{array}{c}\text { Radiocarbon } \\
\text { age } \\
(\mathrm{yr} \mathrm{BP})\end{array}$} & \multicolumn{2}{|c|}{ Calibrated age } & \multirow{2}{*}{$\begin{array}{c}\text { Water depth/ } \\
\text { depth }(\mathrm{m})\end{array}$} \\
\hline & & & & $\begin{array}{l}2 \sigma \text { range } \\
(\text { cal } \mathrm{yr} \mathrm{BP})\end{array}$ & $\begin{array}{c}2 \sigma \text { range } \\
(\mathrm{yr} \mathrm{AD})\end{array}$ & \\
\hline \multicolumn{7}{|c|}{ Lake Poerua } \\
\hline WP7 & 36946 & -23.6 & $357 \pm 15$ & $315-339 \& 353-450$ & $1500-1597 \& 1611-1635^{b}$ & $2.4^{\mathrm{a}}$ \\
\hline WP5 & 29231 & -23.3 & $390 \pm 25$ & $323-414 \& 427-491$ & $1459-1523 \& 1536-1627$ & $2.6^{\mathrm{a}}$ \\
\hline WP4 & 28131 & -24.5 & $454 \pm 30$ & $338-354 \& 449-512$ & $1436-1501 \&$ 1596-1612 & $2.5^{\mathrm{a}}$ \\
\hline WP3 & 29229 & -22.8 & $249 \pm 30$ & $147-220 \& 267-312$ & $1638-1683 \& 1730-1803$ & $1.9^{\mathrm{a}}$ \\
\hline WP26-18 & 28132 & -25.2 & $128 \pm 35$ & $0-143 \& 224-253$ & $1697-1726$ \& $1807-1950$ & $0^{\mathrm{a}}$ \\
\hline WP26-40 & 36945 & -26.4 & $272 \pm 15$ & $155-202 \& 279-314$ & $1636-1671 \& 1748-1795^{b}$ & - \\
\hline WP119-7 & 36564 & -26.5 & $1902 \pm 20$ & $147-220 \& 267-312$ & $1668-1950^{\mathrm{b}}$ & $1.8^{\mathrm{a}}$ \\
\hline WP119-50 & 36565 & -25.1 & $209 \pm 20$ & $0-143 \& 224-253$ & $1654-1697 \& 1725-1808$ & - \\
\hline WP119-97 & 36566 & -26.7 & $162 \pm 20$ & & $1678-1950^{\mathrm{b}}$ & - \\
\hline WP13 & 29673 & -21.1 & $1203 \pm 20$ & $1530-1670$ & - & $0.3^{\mathrm{a}}$ \\
\hline \multicolumn{7}{|c|}{ Evans Creek core } \\
\hline$\overline{\mathrm{EC}}-1$ & 7864 & -25.5 & $709 \pm 75$ & $537-728$ & $1223-1413$ & -6.8 (in core) \\
\hline
\end{tabular}

Note: Radiocarbon age: Conventional radiocarbon age before present (1950 AD) calculated as defined in Stuiver and Polach (1977) using Libby half-life of $5568 \mathrm{yr}$, and normalized to $\delta^{13} \mathrm{C}$ of $-25 \%$. Quoted error is $\pm 1 \sigma$.Calibrated age: calendar years before present (1950 $\mathrm{AD}$ ) and calendar years $\mathrm{AD} / \mathrm{BC}$ using calibration programme Winscal5.0 (๑ Inst Geological and Nuclear Sciences) and Southern Hemisphere atmospheric data from McCormac et al. (2004). A laboratory error multiplier of 1 has been applied to NZA samples. Age ranges listed are minimum and maximum values of the calibrated age range, based on a radiocarbon age error of $\pm 2 \sigma$. (a) Exterior (or close to exterior) wood dates from drowned trees. ${ }^{(b)}$ There are multiple calibration peaks; the range presented is the full range of all calibration peaks.

another stump from which to gain leverage for hand-sawing. On a polished slab section ca. 127 rings were counted to the pithy centre of the tree. Sample WP119-50 represents a sample from several rings that were ca. 43 rings farther into the tree than the outermost sample (WP119-7). This sample yielded an age of $209 \pm 20 \mathrm{yr}$ BP (1654-1808 AD). Finally, sample WP119-97 comprised several rings from near the centre of the tree that are ca. 90 counted rings in from sample WP119-7. This sample yielded an age of $162 \pm 20$ yr BP (1678-1950 AD). In the context of a chronostratigraphy based on annually-accreted tree rings, the three calibrated radiocarbon dates from stump WP119 maintain chronologic consistency.

\section{Interpretation of lake-floor results}

\subsection{Combining ages from similar water depths}

An important observation regarding the dated drowned stumps is that they occur in two water depth ranges. Stump WP3 and the cluster of stumps in the southwest corner of the lake that includes WP119 occur at a similar water depth (ca. 1.7-1.9 m), while stumps WP4, 5 and 7 occur in 2.4$2.6 \mathrm{~m}$ of water. The radiocarbon dated time-of-death ages from the shallower depth range are somewhat younger than the stumps from a greater water depth (but also older than stump WP26). As a first approximation, this suggests a relationship between water depth and age with the possibility that incremental rises in lake level have occurred between the time-of-death ages of the two groups of stumps (Fig. 5).
If we assume that the dates from the exterior of drowned trees WP119 and WP3 now in shallower water are of the same drowning event, then the exterior dates from these stumps may be combined. In this case, the combined weighted radiocarbon age of WP119 and WP3 is $208 \pm 17 \mathrm{yr}$ BP, which calibrates to $1660-1807 \mathrm{AD}$. Similarly, if the exterior ages of the three stumps in deeper water (WP7, WP5 and WP4) are combined, the resultant average weighted radiocarbon age is $379 \pm 12 \mathrm{yr}$ BP (1480$1626 \mathrm{AD})$. These weighted average calibrated ages from two distinct water depth ranges are significantly different at the 2 sigma level.

\subsection{OxCal analysis of dated tree-ring sequences}

Further radiocarbon dates were obtained from stumps WP119 and WP26, where it was possible to extract slab sections from those stumps. The goal was to date small samples taken at intervals across each stump that were separated by a counted number of annual growth rings. This enabled the radiocarbon calibration curve to be used to more precisely estimate when each stump stopped growing (i.e. the time-ofdeath age), using the OxCal program 4.1.7 (Bronk Ramsey, 2010), because single calibrated radiocarbon dates are typically imprecise by nature.

Figure 9 shows the results of an OxCal analysis of the three dates from stump WP119. Each of the dates is placed in ring-growth sequence and the counted interval between rings is established from the number of tree rings between each sampled section (using the "Gap" function). In addition, 


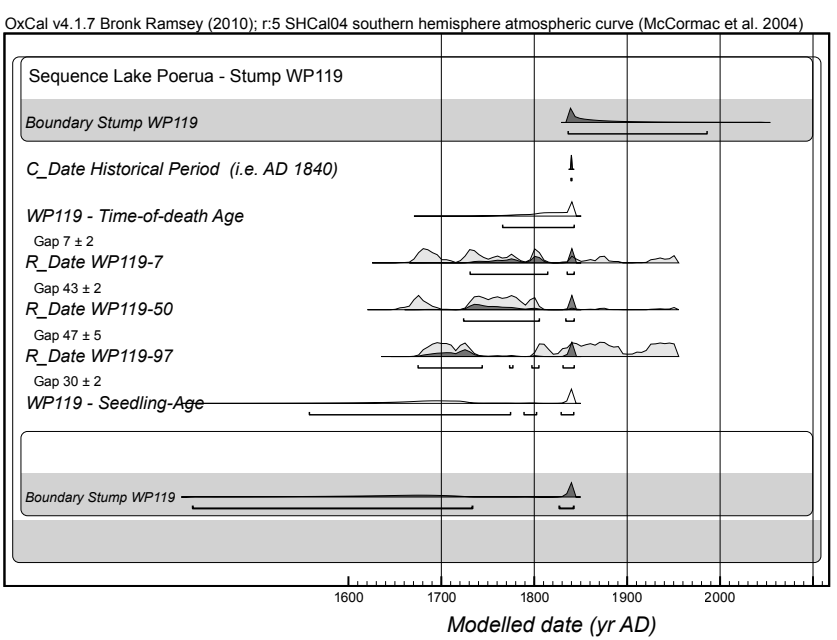

Fig. 9. OxCal plot of calibrated radiocarbon age distributions from tree stump WP119 in Lake Poerua. Dates are stacked from youngest to oldest (at bottom). The light grey probability density functions (PDFs) are prior distributions, while the dark PDFs are posterior or "shaved" distributions using the counted tree ring gaps. The distributions for the time-of-death age and the seedling-age are shown in white.

a historical bound of $1840 \mathrm{AD}$ was added to the younger end of the OxCal analysis. This was added because there is no evidence for surface rupturing earthquakes on the Alpine Fault during the historical period in New Zealand. That is, we make an assumption that the last significant (metre-scale) lake level change happened in association with geologic events that occurred before the settlement of New Zealand by Europeans. However, this assumption does not allow for historical sub-metre changes in lake level. The advantage of adding this $1840 \mathrm{AD}$ bound in $\mathrm{OxCal}$ is to eliminate most of the calibrated probability density function (PDF) for each radiocarbon date that is younger than 1840 . The lifespan of tree WP119 based on ring counting was at least $127 \mathrm{yr}$, which is an estimate of its age from when it had attained a height of ca. $1.6 \mathrm{~m}$ (i.e. from the saw-cut height above the base). The time taken for a native tree to attain a juvenile height such as this is typically about $20-30 \mathrm{yr}$ from the time when the canopy is opened up and a seedling grows to a juvenile height (Wells et al., 1999, 2001; Langridge et al., 2007).

The three radiocarbon dates from WP119 were young (hundreds of yr) and consistent with one another and with respect to the calibration curve. Despite the limitations posed by the radiocarbon calibration curve over this time period, the analysis shows a time-of-death for WP119 between AD 1766 and 1843 (Table 2). The analysis also shows that tree WP119 started growing (seedling age) between 1557 and $1842 \mathrm{AD}$, although both the older and younger ends of this range seem unlikely.

Although there are not enough data to fully determine the life history of tree WP119, it is reasonable to assume that the tree existed for at least ca. $150 \mathrm{yr}$ (including its initial seedling period) between the mid-17th and mid-19th centuries, but most likely died in the late 18th century. A powerful result of using $\mathrm{OxCal}$ and ring counting together is that WP119 could not have been both a seedling and have died in the tight peak in the death and birth PDF's from ca. 1830 1843 AD (Fig. 9), and hence must have started growing well before $1740 \mathrm{AD}$.

Based on ring counts and the radiocarbon dates, the following should be true of WP119: (i) if the tree died as late as $1843 \mathrm{AD}$ then it must have started growing at ca. $1695 \mathrm{AD}$; (ii) if the tree died as early as $1766 \mathrm{AD}$, then it must have started growing at ca. 1615 AD; (iii) WP119 could not have started growing as late as $1842 \mathrm{AD}$; and (iv) it is unlikely that WP119 started growing as early as the older end of the range for probable "birth of WP119" as this is $>150 \mathrm{yr}$ older than the range of "time-of-death of WP119" and also beyond the 2 -sigma range of any of the three radiocarbon dates. Therefore, it is most likely that WP119 lived during the period AD 1616-1842.

An OxCal analysis was also undertaken on stump WP26 from which an entire section with 50 rings was taken at the lake shore. The time-of-death age range of WP26 is 1717$1843 \mathrm{AD}$, and the seedling-age range for it is 1389-1799 AD (Table 2). In this case, given the narrow range for the timeof-death and the short life span of the tree, WP26 probably began growing after ca. $1667 \mathrm{AD}$, but not as late as $1793 \mathrm{AD}$, based on the tree ring count. From the OxCal distributions, it is most likely that WP26 began growing after ca. $1740 \mathrm{AD}$.

\section{Data from rangefront alluvial fans}

\subsection{Core from toe of Evans Creek fan}

A single core was taken from the distal end of the Evans Creek rangefront fan near the northernmost tip of Lake Poerua in 1997 (Fig. 4; Basher et al., 1997). The core retrieved ca. $8 \mathrm{~m}$ of fine-grained clastic to organic deposits. Clastic sediments ranged from coarse sand to fine silt. A plant fragment from within a grey brown silt at a depth of $6.8 \mathrm{~m}$ was radiocarbon dated, yielding an age of $709 \pm 75$ yr BP (1223-1413 AD) (Table 1). Toward the top of the core there is a distinct increase in both the proportion of plant fragments and the number of peat layers in the upper $2.8 \mathrm{~m}$ of the core. This may imply a trend toward greater stability of the fan surface, or a sustained subaerial setting for the fan at that location in more recent times. That is, as the fan built to its current level it became more emergent (subaerial) toward the present at the location of the core.

\subsection{Dendrochronologic data from tree stands on rangefront fans}

Eight kahikatea trees were cored from alluvial fan sites along the rangefront of the Southern Alps east of Lake Poerua 
Table 2. (A) Tree stumps located at given water depths in Lake Poerua and their time-of-death ages. (B) OxCal modelled time-of-death and seedling ages for WP26 and WP119.

\begin{tabular}{llll}
\hline (A) & Rater & & \\
Stump & $\begin{array}{l}\text { Radiocarbon age } \\
\text { depth }(\mathrm{m})\end{array}$ & $128 \pm 35$ & Time-of-death age (cal yr AD) \\
WP26-18 & 0 & $208 \pm 17^{*}$ & $1697-1950$ \\
WP3 \& 119 & $1.7-1.9$ & $379 \pm 12^{*}$ & $1660-1807$ \\
WP4, 5; \& 7 & $2.4-2.6$ & & $1480-1626$ \\
\hline B) & & Lifespan of tree & Time-of-death age (cal yr AD) \\
Stump & Seedling Age & (yr) & $1717-1843$ \\
WP26 & (cal yr AD) & ca. 50 & $1766-1843$ \\
WP119 & $1389-1799$ & ca. 147-157 & \\
\hline
\end{tabular}

*exterior ages are combined to develop a weighted mean which is then calibrated.

(Fig. 4). These trees typically had diameters at coring height of 70-100 cm and several of them had rotten centres. Ring widths were wide implying fast growth rates and none of the cores had more than 270 counted rings. Cored trees with up to $270 \mathrm{yr}$ may correlate well with the re-establishment of forest cohorts on alluvial fans following the most recent Alpine Fault earthquake (1717 AD) that occurred ca. $290 \mathrm{yr}$ before our study (Wells et al., 1999). We also observed several larger standing trees on the flanks of some alluvial fans that are almost certainly older than $270 \mathrm{yr}$. This implies that some remnant trees could have predated the most recent Alpine Fault earthquake (1717 AD) on long-stabilised parts of alluvial fans.

\section{Causes of lake-level rise}

We have documented dead trees rooted in the floor of Lake Poerua and argued for a relative rise in lake level without thus far offering an explanation as to what elevated lake levels. Provided that precipitation (water supply) is relatively constant and abundant (as it is for the West Coast of the South Island), lake-levels will be controlled by a sill or outlet level, above which surplus water spills to a lower base level (Nichols, 2009). This offers the possibility of identifying sill elevations (lake levels) through time, and eliminating those parts of the lake surrounds that were not acting as the sill and were capable of being flooded by rising lake levels. While changes in climate over the last millennium or so is a possible cause for sill or relative base level change, we assert that the major changes in this valley are due to migration (avulsion) of the Taramakau River, and subsequently, in the opportunity of alluvial fans to expand across, and dam the Poerua valley, thus forming a small lake.

Lake Poerua spills into the Poerua River which flows north to Lake Brunner (Fig. 2). The current lake level is controlled by levels of interfingered alluvial fans from rangefront drainages including Dry and Evans/Camp Creeks. These fans have expanded across the valley floor to impinge against the western valley wall, forming the northeastern edge of Lake Poerua (Fig. 4). Growth of these rangefront fans has raised the sill level of the lake to progressively flood lowland forests along at least one former shoreline level, i.e. successively drowning former forests that fringed paleo-shorelines of Lake Poerua.

Growth of these fans is directly attributable to the supply of sediment from the rangefront of the Alpine Fault (Southern Alps) immediately southeast of the lake. Historical studies show that large landslides accompany large earthqukaes and are major sources of sediment from alpine regions (Keefer, 1984; Hancox et al., 2002). Bedrock in the Dry and Evans/Camp Creek catchments comprises Aspiring and Rakaia terrane schist of textural grade III to IV and Alpine Fault mylonite, which form the rangefront of the Southern Alps there (Nathan et al., 2002). These rocks are competent, but fissile, and break down quickly to sand and silt during transport. Exposures show that the alluvial fans are composed almost exclusively of schistose clasts, which contrast with the greywacke-dominated alluvial deposits attributable to the Taramakau River (Langridge et al., 2010).

The headwaters of the Dry and Camp Creek catchments are steep, short $(3-4 \mathrm{~km})$ and characterised by sharp, angular amphitheatres (Fig. 4). These drainages exhibit several large deep-seated landslides and numerous intervening oversteepened faces, of which the latter are relatively fresh and exhibit regenerating scrub and forest. In plan view, the shape and size of the alluvial fans are similar to the catchment areas of the two creeks. We contend that very strong ground motions from Alpine Fault earthquakes are the main driver responsible for the collapse of rangefront slopes as rockfalls and landslides. These release schistose debris into the catchments, which is transported and deposited on the rangefront fans (Pearce and Watson, 1986; Korup et al., 2004). We also recognise that storm events must play an important part in both the erosion and transport of debris from the rangefront to the alluvial fan environment. However, other studies on 
the West Coast have shown that despite the high mean rainfall along the west side of the South Island (6-9 m annually), the main driver in forming terraces and sedimentary deposits are large to great earthquakes (e.g. Berryman et al., 2009).

Earthquake-generated landsliding may have been punctuated in time, with large initial collapses from rangefront slopes and smaller, subsequent slides that occurred as a result of aftershocks over months to years following large to great Alpine Fault earthquakes. The presence of remnant submature podocarp forest on these fan surfaces today implies that they were reactivated, stabilised and then remained stable during the last $270 \mathrm{yr}$ or so. During that time sediment outflows from Dry and Camp Creeks have been confined to entrenched fan-head channels that flow out to the lake and Poerua River. This implies that the expansion of these fans in area and volume has been punctuated in time, after which time an equilibrium state is re-established. Lake-level maxima may in fact occur prior to fan-head entrenchment.

What do we know of the stratigraphy of the rangefront fans? The core taken from the toe of the Evans Creek fan encountered fine-grained clastic to organic deposits. These clastic sediments are interpreted as distal alluvial fan deposits. A plant fragment dated from a depth of $6.8 \mathrm{~m}$ in the core yielded a calibrated age of 1223-1413 AD. The $8 \mathrm{~m} \mathrm{sec}-$ tion of distal fan deposits corresponds closely with the maximum depth $(6.7 \mathrm{~m})$ of Lake Poerua (Fig. 4), allowing for the extrapolated slope of the underlying outwash surface from the Taramakau River that forms the lake floor (former I-3 surface). This suggests that the depth of the lake is directly proportional to the sediment thickness in the adjoining rangefront fans, i.e. they roughly grade to each other. Therefore, it would be reasonable to correlate incremental metre-scale rises in the level of Lake Poerua to equivalently-thick additions of sediment across the rangefront fans. The sedimentary fill of the lake has not been investigated, however, it is evident that at shallow water depths at the south end of the lake (up to $2.5 \mathrm{~m}$ ), tree stumps on the lake floor are not significantly buried by sediment being deposited in the lake from adjacent runoff. This implies a low sedimentation rate across most of Lake Poerua where alluvial fans are not present.

\section{Discussion}

\subsection{Timing of recent lake-level change events}

We suggest two abrupt lake-level rises for Lake Poerua in the last 400-600 yr. Based on the weighted mean average of three tree stumps at $2.4-2.6 \mathrm{~m}$ water depth, the older lake level rise event occurred at or after 1480-1626 AD. However, because one of the trees (WP5) was identified as a Matai (Prumnopitys taxifolia), a water-intolerant podocarp, the lake must have risen from substantially below these trees (i.e. water level $>2.6 \mathrm{~m}$ below present) to above their root base. Because the Matai probably died soon after the lake level began
Table 3. Relationship between the preferred timing of lake rise events in Lake Poerua and Alpine Fault earthquake ages.

\begin{tabular}{lll}
\hline Lake Rise event & $\begin{array}{l}\text { Timing (a) } \\
\text { (cal yr AD) }\end{array}$ & $\begin{array}{l}\text { Alpine Fault earthquake } \\
\text { ages (cal yr AD) }\end{array}$ \\
\hline Most recent & $1766-1807$ & 1717 \\
Intermediate (b) & & $1615 \pm 5$ \\
& & $1430 \pm 15$ \\
Initial & $1225-1415$ & $1230 \pm 50$ \\
\hline
\end{tabular}

(a) Preferred ages for rises in lake level, see text for details. (b) The intermediate event can be intimately tied to the timing of either of the corresponding Alpine Fault events.

rising, it provides a better constraint on the timing of this lake level rise to ca. 1459-1626 AD (Table 3).

A younger lake level rise event is indicated by the average calibrated age (1660-1807 AD) of the exterior of two kahikatea stumps in $1.7-1.9 \mathrm{~m}$ of water. A detailed dating analysis using OxCal and based on three dates from counted tree ring sections from stump WP119 yielded a time-ofdeath age for this stump of 1766-1843 AD. OxCal analysis also indicates that this $150 \mathrm{yr}$ old tree lived and died during the period ca. 1616-1842 AD. We interpret the overlap between these three intervals, (i.e. ca. 1766-1807 AD), as representing the most likely time-of-death of kahikatea that were growing at this elevation at that time (Table 3 ). Considering the tolerance of kahikatea to waterlogged conditions (perhaps up to $40 \mathrm{~cm}$ water), the magnitude of this younger lake level rise was approximately $1.3-1.8 \mathrm{~m}$.

Tree WP26 "seeded" on the wave-cut shorefront of the scarp of the Alpine Fault at the southeastern edge of the lake (Fig. 4). That shore platform must have been cut once the lake deepened and expanded up to the scarp of the fault. We infer that this rise occurred following the most recent Alpine Fault rupture in 1717 AD. This implies that WP26 lived and died over a 50-60 yr period between ca. 1717-1843 AD and most likely began growing after ca. 1740 AD.

Historical lake-level changes also offer insight into the record of past lake levels. Perennial visits to the lake have shown that the seasonal level of Lake Poerua can vary by $10-30 \mathrm{~cm}$, which is similar to the tolerance of kahikatea that grow around the fringes of the lake. Records show that Lake Poerua was elevated between January and August 1991 following a small landslide from Mt. Te Kinga in the Brums Creek catchment (Golder Associates, 2007; M. Trayes, personal communication, 2011). At this time, a small debris cone originating from the creek may have been responsible for temporarily blocking the Poerua River and raising the lake and flooding farm land at the northeastern end of the lake (Fig. 4). Anecdotal hearsay says that farmers acted quickly to remove some of the debris and eliminate continued flooding of the land. This episode suggests that short-term (as well as seasonal) lake-level rises affect Lake Poerua; however, 
scouring by the Poerua River can remove debris and restore the system back to a former equilibrium sill level.

Our interpretation favours punctuated, metre-scale changes in the level of Lake Poerua over years to decades, as opposed to gradual lake level rise with time. Some of the best evidence to support this is the very high sedimentation rate of the rangefront fans from the core $(1 \mathrm{~m} / 100 \mathrm{yr})$, but relatively stable fan surfaces during the historic period, that have trees of up to $270 \mathrm{yr}$ old growing on them today. Thus, the expansion of alluvial fans as a consequence of abrupt sediment supply due to landsliding and rockfalls is punctuated and leads to abrupt lake level changes in Lake Poerua.

\subsection{Relationship between lake level rise and Alpine Fault ruptures}

Abrupt changes in the landscape of the West Coast coastal plains have been linked to past large to great $\left(M_{\mathrm{w}}=7.8\right.$ 8) earthquake rupture events on the Alpine Fault (Yetton, 2000; Berryman et al., 2009; Wells and Goff 2007; Wells et al., 1999, 2001). Wells and Goff (2007) list the most recent Alpine Fault earthquake ages as 1826, 1717, ca. 1615, ca. 1430 and ca. $1230 \mathrm{AD}$. The $1826 \mathrm{AD}$ event is widely considered to have occurred on the southern or offshore sections of the Alpine Fault, or even the Puysegur subduction zone in Fiordland (Fig. 1). The most recent rupture event along the central section of the Alpine Fault occurred at ca. $1717 \mathrm{AD}$ based on dendrochronologic records from trees growing on landslide scars and deposits, alluvial fans, terraces and coastal dunes, and from the recognition of growth suppression and release seen in tree rings that indicate stresses on forest populations. Paleoseismic trench sites within $40 \mathrm{~km}$ of Lake Poerua at Toaroha River, Inchbonnie and Haupiri (Fig. 1) show evidence of an Alpine Fault rupture that coincides with the $1717 \mathrm{AD}$ event (Yetton, 2000; Langridge et al., 2009). Therefore, it is likely that the most recent rupture of the Alpine Fault along the rangefront adjacent to Lake Poerua occurred during the 1717 AD earthquake.

Both of the documented $1615 \mathrm{AD}( \pm 5 \mathrm{yr})$ and $1430 \mathrm{AD}$ $( \pm 15 \mathrm{yr})$ landscape change events are correlated with rupture of either the central or northern sections of the Alpine Fault (Yetton, 2000; Yetton and Wells, 2010). Age control from the Inchbonnie trench site (Langridge et al., 2009; Langridge et al., 2010) is poor but does not discount that either of these events could have ruptured through the Lake Poerua area. Much of the fault trace and fault rupture evidence in this area is buried by subsequent growth of rangefront alluvial fans. It is not yet possible to link the penultimate rise in the level of Lake Poerua with a specific Alpine Fault rupture, however, either of the ca. 1615 AD or $1430 \mathrm{AD}$ Alpine Fault events could be linked with that rise.

In the next section we argue that the initial formation of the rangefront fans may have come from landsliding related to collapse of rangefront slopes in association with the $1230 \mathrm{AD}$ $( \pm 50)$ Alpine Fault rupture event. Thus, we consider it likely that there is a direct relationship between the timing of fault rupture events on the Alpine Fault, rockfall and landsliding, growth of rangefront alluvial fans, expansion (lake level rise) of Lake Poerua, and drowning of lowland forests previously growing above Lake Poerua shorelines. Based on radiocarbon dating undertaken on the drowned trees, we contend that this series of processes, culminating in stabilisation of the fans and new lake level, takes only years to decades following the seismic shaking event, based on the age of living kahikatea cored on rangefront alluvial fans and the life history of stump WP26.

\subsection{Late Holocene history of Lake Poerua}

Figure 10 illustrates the late Holocene history of the Lake Poerua area. The Taramakau River flowed through the area, depositing alluvial greywacke gravels in the Poerua sub-lobe of the valley prior to ca. $1530-1670$ cal yr BP (420-340 AD) (Fig. 10d; Langridge et al., 2010). From this time onward, valley-wide alluviation diminished as the river avulsed to the southwest, and thus the recent geomorphic features of the valley floor including Lake Poerua and the rangefront fans were able to develop. Also since that time, ruptures of the Alpine Fault began to build the large scarp that currently bounds the southeastern shore of the lake and toward Inchbonnie (Fig. 7) (Langridge et al., 2010). Based on the age and thickness of fan sediments cored at the toe of the rangefront fans, Lake Poerua may have initially existed as a very shallow (ca. $1-2 \mathrm{~m}$ deep) proto-lake, controlled by a low sill near the western fringes of the rangefront fans. Alternatively, based on the lake bathymetry and Evans Creek core, removing 7-8 $\mathrm{m}$ of alluvial fan material that has been deposited since ca. $1225 \mathrm{AD}$ would eliminate the need for all but a wetland pond within the valley prior to this time. In this case, Lake Poerua developed wholly as a consequence of the building of a sill caused by the deposition of fan sediments from the rangefront fan catchments. This in itself implies that intense landsliding and collapse of the rangefront took place since ca. 1225-1415 AD. Ground shaking from Alpine Fault earthquakes is a logical trigger for the landsliding and consequent sediment yield. Both ends of this calibrated age distribution correspond with landscape change events at other sites that are linked with Alpine Fault ruptures (Yetton, 2000; Wells and Goff, 2007). We infer that the ca. $1230 \mathrm{AD} \pm 50 \mathrm{yr}$ Alpine Fault earthquake locally caused major landsliding, consequent deposition and expansion of the rangefront fans, and the formation of proto-Lake Poerua in this area (Fig. 10c).

In the centuries that followed, forests - based on the presence of large (ca. $0.5 \mathrm{~m}$ diameter) podocarp and kahikatea trees (stumps WP7, WP5 and WP4) on the now-drowned valley floor - provide evidence of stability of the landscape 

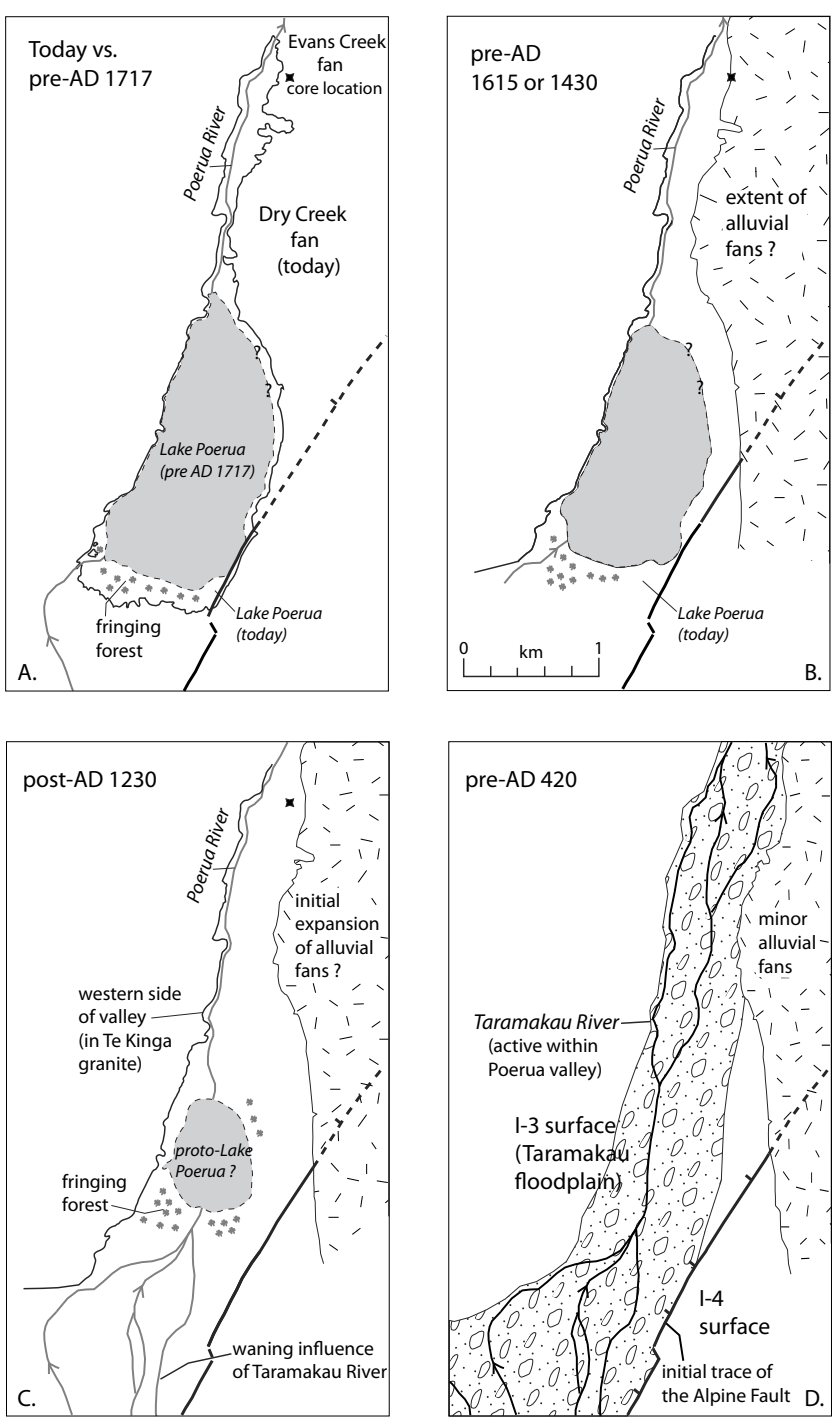

Fig. 10. Late Holocene history of Lake Poerua. (A) Lake Poerua as it occurs today (dark outline) and prior to the most recent Alpine Fault earthquake (light grey); (B) the lake as it appeared prior to the penultimate lake level rise. (C) proto-Lake Poerua as it may have existed near the time of the ca. $1230 \mathrm{AD}$ Alpine Fault earthquake; (D) the Poerua valley prior to AD 400 when the Taramakau River flowed within it. Bold lines represent the inferred presence of traces of the Alpine Fault at those times.

around proto-Lake Poerua. These trees were drowned in a rise in the lake between the mid-15th to early 17 th centuries (Fig. 10b). We attribute this rise to further rapid growth of the rangefront fans following either the 1430 or $1615 \mathrm{AD}$ Alpine Fault earthquakes. A subsequent rise in Lake Poerua to nearmodern levels caused the drowning of fringing forests, including trees WP119, WP3 now in a water depth of $2 \mathrm{~m}$ or less. This lake level rise is indirectly linked to the $1717 \mathrm{AD}$ Alpine Fault earthquake (Fig. 10a). Immediately prior to this rise a shoreline level must have existed somewhere between, or within $\pm 0.5 \mathrm{~m}$ of, these stumps and the deeper, earlier drowned trees, e.g. WP7.

Shortly following the 1717 AD Alpine Fault earthquake, Lake Poerua expanded and deepened to close to its current level. Evidence from the dating of WP26 suggests that a wave cut platform at the height of the modern lake level was cut by ca. 1740 AD. Meanwhile, kahikatea now found in ca. $2 \mathrm{~m}$ of water may not have died until $1766 \mathrm{AD}$ or later. These results suggest that while the rangefront alluvial fans probably expanded and stabilised within a decade or so of the Alpine Fault earthquake, and that while the lake responded by filling and cutting a wave-cut shoreline, that kahikatea in the lake lived on for decades under extreme water-level conditions. Young buttressed kahikatea trees are currently growing in up to $40 \mathrm{~cm}$ of water at the lake shore and within the lake shallows, which attests to the tree's ability to cope with a very high water table.

\section{Conclusions}

Precise chronologies obtained using radiocarbon dates and OxCal analyses, and dendrochronologic studies show that a series of landscape changes beginning with fault rupture, followed by landsliding, leading to fan sedimentation and lake expansion, and culminating in stabilisation of the alluvial fan complexes may take many years to decades to complete. Three such punctuated cycles of alluvial fan and lake expansion are linked to three of the last four Alpine Fault earthquake ages at ca. 1717, 1615 or 1430 , and $1230 \mathrm{AD}$. These results confirm that large to great earthquakes on the Alpine Fault are agents of massive landscape change along the western side of the South Island. Based on dating in this study, the impacts of each landscape change event could be at their most severe for up to a decade or so following the earthquake that triggered them, after which time podocarp trees colonise stabilised alluvial fans. Our results also suggest that kahikatea trees are not particularly sharp indicators of drowning (lake level rise) events, because they have a tendency to survive sufficiently well with an extreme elevated water table for up to several decades.

Future work may include using SCUBA to investigate the lake floor for the presence of drowned stumps at greater depths toward the centre of the lake. This novel study is important as it provides a link between trenching and landscape change studies in a proximal setting, i.e. in an area where there is a mergence between on-fault and off-fault paleoseismic studies that are typically medial to distal in distance from the fault rupture source.

Acknowledgements. The authors acknowledge the Department of Conservation for permission to sample wood from the Lake Poerua area. We also thank Bob Williams for use of kayaks to undertake field work. Greg De Pascale and Eric Daniels provided assistance in the field. Mauri McSaveney, Mike Page, Gavin Dunbar, Geoffroy 
Lamarche and an anonymous reviewer are thanked for their reviews which significantly improved the quality of this paper. This work was funded through the FRST project Impacts of Plate Tectonics in New Zealand (PLT): Alpine Fault earthquake geology (PGST Contract CO5X0702).

Edited by: G. Lamarche

Reviewed by: G. Dunbar and another anonymous referee

\section{References}

Adams, J.: Paleoseismicity of the Alpine fault seismic gap, Geology, 8, 72-76, 1980.

Alloway, B. V., Lowe, D. J., Barrell, D. J. A., Newnham, R. M., Almond, P. C., Augustinus, P. C., Bertler, N. A. N., Carter, L., Litchfield, N. J., McGlone, M. S., Shulmeister, J., Vandergoes, M. J., Williams, P. W., and NZ-INTIMATE members: Towards a climate event stratigraphy for New Zealand over the past 30 000 years (NZ-INTIMATE project), J. Quaternary Sci., 22, 935, 2007.

Barrell, D. J. A., Andersen, B. G., and Denton, G. H.: Glacial geomorphology of the central South Island, New Zealand, Lower Hutt: GNS Science, GNS Science monograph, 27. 2 v., 2011.

Basher, L., Wilmshurst, J., and Moar, N.: Progress report - Alpine Fault history and hazards, Landcare Research New Zealand, Lincoln, Unpublished Report, 1997.

Berryman, K. R., Beanland, S., Cooper, A. F., Cutten, H. N., Norris, R. J., and Wood, P. R.: The Alpine Fault, New Zealand: variation in Quaternary structural style and geomorphic expression, Annales Tectonicae, 5, 126-163, 1992.

Berryman, K., Almond, P., Villamor, P., Read, S., Tonkin, P., and Alloway, B.: Alpine Fault ruptures shape the geomorphology of Westland, New Zealand: Data from the Whataroa catchment, Geomorphology 2009, ANZIAG 7th International Conference on Geomorphology, Melbourne, 2009.

Berryman, K. R., Cooper, A., Norris, R., Villamor, P., Sutherland, R., Langridge, R., Wright, T., Schermer, E., and Biasi, G. P.: Late Holocene rupture history of the Alpine Fault in South Westland, New Zealand, Bull. Seism. Soc. Am., 102, 620-638, doi:10.1785/0120110177, 2012.

Biasi, G. and Weldon, R. J.: Quantitative refinement of calibrated C-14 Distributions, Quaternary Res., 41, 1-18, 1994.

Bronk, R.: OxCal Program, v. 4.1.7, Radiocarbon Accelerator Unit, University of Oxford, UK, available at: https://c14.arch.ox.ac.uk/ embed.php?File=oxcal.html, 2012.

Cavinato, G. P., Gliozzi, E., and Mazzini, I.: Two lacustrine episodes during the late Pliocene-Holocene evolution of the Rieti Basin (Central Apennines, Italy), in: Gierlowski-Kordesch, edited by: Gierlowski-Kordesch, E. H., and Kelts, K. R., Lake basins through time and space, AAPG Studies in Geology \#46, 527534, The American Association of Petroleum Geologists, USA, 2000

Clague, J. J.: Evidence for large earthquakes at the Cascadia Subduction Zone, Rev. Geophys., 35, 439-460, 1997.

Cox, S. C. and Sutherland, R.: Regional geologic framework of South Island, New Zealand, and its significance for understanding the active plate boundary, in: A continental plate boundary: tectonics at South Island, edited by: Okaya, D., Stern, T. and
Davey, F., New Zealand, Geophysical Monograph, 175, 19-46, 2007.

Cullen, L. E., Duncan, R. P., Wells, A., and Stewart, G. H.: Floodplain and regional scale variation in earthquake effects on forests, Westland, New Zealand, J. Roy. Soc. N. Z., 33, 693-701, 2003.

Dawson, J. and Lucas, R.: New Zealand native trees, Craig Potton Publishing, Nelson, New Zealand, 2011.

De Mets, C., Gordon, G., Argus, D. F., and Stein, S.: Effect of recent revisions to the geomagnetic reversal time scale on estimates of current plate motions, Geophys. Res. Lett., 21, 2191-2194, 1994.

Golder Associates: Geotechnical Site Suitability Assessment for Proposed Subdivision at Lake Poerua, Westland. Ref. \# R06812016-02-V2, 2007.

Goldfinger, C.: Subaqueous paleoseismology, in: Paleoseismology, edited by: McCalpin, J. P., 2nd Edn., Elsevier Inc., 119-170, 2009.

Hancox, G. T., Perrin, N. D., and Dellow, G. D.: Recent studies of earthquake-induced landsliding, ground damage, and MM intensity in New Zealand, Bull. N. Z. Soc. Earthq. Engg., 35, 59-95, 2002.

Hibsch, C., Alvarado, A., Yepes, H., Bebrier, M., and Perez, V. H.: Holocene Seismicity and tectonic activity of the Quito Fault (Ecuador): A paleoseismic history recoded in lacustrine sediments, Third ISAG Meeting, St. Malo, France, 1996.

Howarth, J., Fitzsimons, S. J., Norris, R. J., Jacobsen, G. E., and Strong, D. T.: Reconstructing earthquake-driven erosion in the Southern Alps, New Zealand using the sedimentary record, American Geophysical Union, Fall Meeting, San Francisco, Calif., USA, 2011.

Irwin, J.: Lake Ianthe: Lake Poerua bathymetry, 1:8000, N.Z. Oceanographic Institute Chart, Lake Series, 1982.

Jacoby, G. C., Bunker, D. E., and Benson, B. E.: Tree-ring evidence for an A.D. 1700 Cascadia earthquake in Washington and northern Oregon, Geology, 25, 999-1002, doi:10.1130/00917613, 1997.

Kagan, E., Stein, M., Agnon, A., and Neumann, F.: Intrabasin paleoearthquake and quiescence correlation of the late Holocene Dead Sea, J. Geophys. Res., 116, B04311, doi:10.1029/2010JB007452, 2011.

Keefer, D. K.: Landslides caused by earthquakes, Geol. Soc. Am. Bull., 95, 406-421, 1984.

Korup, O., McSaveney, M. J., and Davies, T. R. H.: Sediment generation and delivery from large historic landslides in the Southern Alps, New Zealand, Geomorphology, 61, 189-207, 2004.

Langridge, R. M. and Berryman, K. R.: Morphology and slip rate of the Hurunui section of the Hope Fault, South Island, New Zealand, N. Z. J. Geol. Geophys., 48, 43-58, 2005.

Langridge, R. M. and McSaveney, M.: Updated review of proposed Lake Poerua subdivision, Grey District, GNS Science Consultancy Report 2008/11, 2008.

Langridge, R. M., Pezzopane, S. K., and Weldon, R. J.: Slip rate, recurrence intervals and paleoearthquakes for the Ana River Fault, central Oregon, Friends of the Pleistocene, 9th Annual Pacific Northwest Cell Field Trip Volume, 2001.

Langridge, R., Duncan, R., Almond, P., and Robinson, R.: Indicators of paleoseismic activity along the western Hope Fault, GNS Science Consultancy Report 2006/151, 2007.

Langridge, R. M., Villamor, P., Almond, P., Basili, R., HemphillHaley, M. and Ries, W.: Late Holocene paleoseismicity of the 
Australia-Pacific plate boundary in central South Island: The Alpine to Hope Fault transition. Geological Society of America Abstracts with Programs, 41, 691 pp., Portland, Oregon, 2009.

Langridge, R. M., Villamor, P., Basili, R., Almond, P., MartinezDiaz, J. J., and Canora, C.: Revised slip rates for the Alpine fault at Inchbonnie: Implications for plate boundary kinematics of South Island, New Zealand, Lithosphere, 2, 139-152, doi:10.1130/L88.1, 2010.

McCalpin J. P.: Paleoseismology, 2nd Edn., Elsevier Inca., 613 pp., 2009.

McCormac, F. G., Hogg, A. G., Blackwell, P. G., Buck, C. E., Higham, T. F. G., and Reimer, P. J.: SHCAL04 Southern Hemisphere calibration 0-11.0 kyr BP: Radiocarbon, 46, 1087-1092, 2004.

Marco, S., Stein, M., Agnon, A., and Ron, H.: Long-term earthquake clustering: A 50,000-year paleoseismic record in the Dead Sea Graben, J. Geophys. Res,. 101, 6179-6191, 1996.

Marco, S., Hartal, M., Hazan, N., Lev, L., and Stein, M.: Archaeology, history, and geology of the 749 AD earthquake, Dead Sea Transform, Geology, 31, 665-668, doi:10.1130/G19516.1, 2003.

Negrini, R. M.: Pluvial lake sizes in the northwestern Great Basin throughout the Quaternary Period, in: Great Basin Aquatics Systems History, edited by: Currey, D., Madsen, D., and Hershler, R., Smithson, Contr. Earth Sci., Smithsonian Press, 31, 17-59, 2002.

Nelson, A. R., Atwater, B. F., Bobrowsky, P. T., Bradley, L., Clague, J. J., Carver, G. A., Darienzo, M. E., Grant, W. C., Krueger, H. W., Sparks, R., Stafford, T. W., and Stuiver, M.: Radiocarbon evidence for extensive plate-boundary rupture about 300 years ago at the Cascadia subduction zone, Nature, 378, 371374, doi:10.1038/378371a0, 1995.

Nathan, S., Rattenbury, M. R., and Suggate, R. P.: Geology of the Greymouth area: Institute of Geological and Nuclear Sciences 1: 250000 geological map 12, 1 sheet +65 pp., Lower Hutt, New Zealand: Institute of Geological and Nuclear Sciences, 2002.

Nichols, G.: Sedimentology and stratigraphy, 2nd Edn., WileyBlackwell, 419 pp., 2009.

Norris, R. J. and Cooper, A. F.: Late Quaternary slip rates and slip partitioning on the Alpine Fault, New Zealand, J. Struct. Geol., 23, 507-520, 2001.

Pearce, A. J. and Watson, A.: Effects of earthquake induced landslides on sediment budget and transport over a 50-year period, Geology, 14, 52-55, 1986.

Philibosian, B., Fumal, T., and Weldon, R.: San Andreas Fault Earthquake Chronology and Lake Cahuilla History at Coachella, California. Bull. Seismol. Soc. Am., 101, 13-38, 2011.

Reid, I. and Frostick, L.: Late Pleistocene rhythmite sedimentation at the margin of the Dead Sea Trough: a guide to paleoflood frequency, in: Geomorphology and sedimentology of lakes and reservoirs, edited by: McManus, J. and Duck, R. W., John Wiley and Sons, Chichester, England, 1993.

Rhoades, D. A. and Van Dissen, R. J.: Estimates of the time-varying hazard of rupture of the Alpine Fault, allowing for uncertainties, N. Z. J. Geol. Geophys., 46, 479-488, 2003.

Sims, J.: Determining earthquake recurrence intervals from deformational structures in young lacustrine sediments, Tectonophysics, 29, 141-152, 1975.

Smith, G. I.: Late Pliocene and Pleistocene Searles Lake, California, USA, in: Lake basins through time and space, edited by:
Gierlowski-Kordesch, E. H. and Kelts, K. R., AAPG Studies in Geology \#46, The American Association of Petroleum Geologists, USA, 591-596, 2000.

Stuiver, M. and Polach, H. A.: Discussion: Reporting of ${ }^{14} \mathrm{C}$ data, Radiocarbon, 19, 355-363, 1977.

Suggate, R. P.: Late Pleistocene geology of the northern part of the South Island, New Zealand, New Zealand Geological Survey Bulletin 77, N. Z. Dept. of Sci. Industr. Res., Wellington, New Zealand, 91 pp., 1965.

Suggate, R. P. and Waight, T. E.: Geology of the Kumara-Moana area, scale 1:50000: Institute of Geological and Nuclear Sciences geological map 24, 1 sheet + 124 pp., 1999.

Sutherland, R., Berryman, K. R., and Norris, R. J.: Quaternary slip rate and geomorphology of the Alpine fault: implications for the kinematics and seismic hazard in southwest New Zealand, Geol. Soc. Am. Bull., 118, 464-474, 2006.

Sutherland, R., Eberhart-Phillips, D., Harris, R. A., Stern, T., Beavan, J., Ellis, S., Henrys, S., Cox, S., Norris, R. J., Berryman, K. R., Townend, J., Bannister, S., Pettinga, J., Leitner, B., Wallace, L., Little, T. A., Cooper, A. F., Yetton, M., and Stirling, M.: Do great earthquakes occur on the Alpine Fault in central South Island, New Zealand?, in: A continental plate boundary: tectonics at South Island, New Zealand, edited by: Okaya, D., Stern, T. and Davey, F., Geophysical Monograph, 175, 235-251, 2007.

Van Dissen, R. and Yeats, R.: Hope fault, Jordan thrust, and uplift of the Seaward Kaikoura Range, New Zealand, Geology, 19, 393396, 1991.

von Haast, H. F.: The life and times of Sir Julius von Haast, Avery Press Limited, New Plymouth, New Zealand, 1142 pp. and maps, 1948.

Wardle, P.: The kahikatea (Dacrycarpus dacrydioides) forest of south Westland, Proc. N. Z. Ecol. Soc., 21, 62-71, 1974.

Wellman, H. W.: New Zealand quaternary tectonics, Geol. Runds., 43, 248-257, 1955.

Wells, A. and Goff, J.: Coastal dunes in Westland, New Zealand, provide a record of paleoseismic activity on the Alpine Fault, Geology, 35, 731-734, 2007.

Wells, A., Duncan, R. P., and Stewart, G. H.: Forest dynamics in Westland, New Zealand: the importance of large, infrequent earthquake-induced disturbance, J. Ecol., 89, 1006-1018, 2001.

Wells, A., Yetton, M. D., Duncan, R. P., and Stewart, G. H.: Prehistoric dates of the most recent Alpine fault earthquakes, New Zealand, Geology, 27, 995-998, 1999.

Yetton, M. D.: Progress in understanding the paleoseismicity of the central and northern Alpine Fault, Westland, New Zealand, N. Z. J. Geol. Geophys., 41, 475-483, 1998.

Yetton, M. D.: The probability and consequences of the next Alpine Fault earthquake, South Island, New Zealand: Doctor of Philosophy thesis, Dept. of Geological Sciences, University of Canterbury, Christchurch, New Zealand, 2000.

Yetton, M. D. and Wells, A.: Earthquake rupture history of the Alpine fault over the last 500 years, in: Geologically Active - Proceedings of the 11th IAEG Congress. Auckland, New Zealand, 5-10 September 2010, edited by: Williams, A. L., Pinches, G. M., Chin, C. Y., McMorran, T. J., and Massey, C. I., Taylor and Francis Group, London, 2010. 